TITLE:

\title{
The first assessment of cyanobacterial and diazotrophic diversities in the Japan Sea
}

\section{AUTHOR(S):}

Hashimoto, Ryoya; Yoshida, Takashi; Kuno, Sotaro; Nishikawa, Tetsuya; Sako, Yoshihiko

\section{CITATION:}

Hashimoto, Ryoya ... [et al]. The first assessment of cyanobacterial and diazotrophic diversities in the Japan Sea. Fisheries Science 2012, 78(6): 1293-1300

\section{ISSUE DATE:}

2012-11

URL:

http://hdl.handle.net/2433/163407

RIGHT:

The final publication is available at www.springerlink.com 
2 The first assessment of cyanobacterial and diazotrophic diversities in the Japan Sea

3

\section{Authors}

5 Ryoya Hashimoto ${ }^{1}$, Takashi Yoshida ${ }^{1}$, Sotaro Kuno ${ }^{1}$, Tetsuya Nishikawa ${ }^{2}$ and Yoshihiko Sako ${ }^{1}$

6

$7 \quad$ Affiliation

$8{ }^{1}$ Graduate School of Agriculture, Kyoto University, Kyoto 606-8502, Japan, ${ }^{2}$ Tajima Fisheries

9 Technology Institute, Hyogo Prefectural Technology Center for Agriculture, Forestry and Fisheries,

10 Kasumi, Kami, Mikata, Hyogo 669-6541, Japan

11

12 Corresponding author. Postal address: Faculty of Agriculture, Kitashirakawa-Oiwake, Sakyo-ku, Kyoto

13 606-8502, Japan. Phone: (+81) 75-753-6218. Fax: (+81) 75-753-6226. E-mail:

14 yoshiten@kais.kyoto-u.ac.jp

15 


\section{Abstract}

17 The diversity of cyanobacteria and dizaotrophs in the Japan Sea was investigated by analyzing sequences

18 of cyanobacterial 16S rRNA genes and nitrogen fixation genes (nifH) from seawater sampled at a depth

19 ranging from surface to $100 \mathrm{~m}$ at two stations. Of the 107 cyanobacterial $16 \mathrm{~S}$ rRNA gene sequences

20 obtained, 97 sequences and 3 sequences were assigned to Synechococcus sub-cluster 5.1 and

21 Prochlorococcus HL (II), respectively. Unlike other oceanic regions, compositional ratio of the sequences assignable to Synechococcus sub-cluster 5.3 was relatively high (8\%). No sequences of diazotrophic cyanobacteria were found in the cyanobacterial 16S rRNA genes. In nifH clone library (36 sequences), 10 sequences were identified as a UCYN-A group of diazotrophic cyanobacteria. Residual 26 sequences (72\%) were assigned to proteobacteria. These results suggest heterotrophic bacteria including UCYN-A dominated in diazotrophic community in the Japan Sea. Our study revealed the dominance of Synechococcus in cyanobacterial community and (photo)heterotrophic diazotrophs in diazotrophic community in the Japan Sea, suggesting its unique characteristics. 
Marine cyanobacteria, especially two genera, Prochlorococcus and Synechococcus, significantly contribute to $32-80 \%$ of the primary productivity in various oceanic regions [1-3]. Some other cyanobacteria retain ability for $\mathrm{N}_{2}$ fixation which is the process of reducing $\mathrm{N}_{2}$ gas to biologically available ammonium (referred to as diazotrophic cyanobacteria). The biological $\mathrm{N}_{2}$ fixation is carried out by several species of bacteria and archaea, but mainly by diazotrophic cyanobacteria in the ocean [4]. Therefore, marine cyanobacteria play an important role in carbon cycle as well as in nitrogen cycle. Among marine diazotrophic cyanobacteria, filamentous nonheterocystous Trichodesmium spp. are the most abundant diazorophs in the ocean. Trichodesmium spp. are observed throughout the tropical and subtropical Atlantic, Pacific, Indian oceans, and East and South China seas [5,6]. In North Atlantic Ocean, their contribution to nitrogen inputs can be as great or greater than nitrate advection from deep sea water [7]. In addition, heterocystous cyanobacterial diatom symbionts such as Richelia spp. and Calothrix spp. have also been considered to make a significant contribution to $\mathrm{N}_{2}$ fixation in North Atlantic Ocean and North Pacific Ocean [8,9]. They are detected in tropical and subtropical regions in North Pacific Ocean and North Atlantic Ocean [10,11]. Recently, some unicellular cyanobacteria have been recognized as important diazotrophs in the ocean [12-14]. The unicellular diazotrophic cyanobacteria (UCYN) are phylogenetically sub-divided into three groups, UCYN-A, B and C based on amino acid sequences of NifH (dinitrogenase reductase), a subunit of the nitrogenase complex enzyme. UCYN-A is an uncultivated cyanobacterium lacking oxygenic photosystem II, ribulose bisphosphate carboxylase 
UCYN-A is shown to be more abundant than other two groups with broad latitudinal range in the North shows a patchy distribution in the ocean, and is detected in South Pacific, Eastern Atlantic, and North Pacific $[10,14,16]$. Compared to the other two unicellular diazotrophic cyanobacterial groups, UCYN-C including Cyanothece TW3 has less abundance in the open ocean [17,18]. islands and Asian continent. The Japan Sea is often referred to as "the miniature ocean" because the situation, which the course of the western branch of the Tsushima Current and the cold water generated in north and the warm water in east, is similar to those of the global ocean [19]. Its water exchange is limited in the upper layer because the Japan Sea is connected to adjacent seas with the shallow straits [19]. Although many studies have examined the diversity of cyanobacteria in various oceanic regions, less is known about the diversity of cyanobacteria, especially diazotrophic cyanobacteria in the Japan Sea. and nifH genes.

Materials and Methods

Seawater collection 
was collected in 21 Niskin bottles mounted on a CTD (SBE-9 plus, Sea Bird Electronics) rosette from

$0,10,30,75,100 \mathrm{~m}$, and deep chlorophyll maximum (DCM, near 50m). We measured profiles of temperature, salinity, and concentrations of chlorophyll a using the CTD.

\section{DNA extraction}

Each $300 \mathrm{ml}$ sample was filtered through $0.2 \mu \mathrm{m}$ pore-size polycarbonate filters (ADVANTEC, Tokyo,

Japan), and then filters were wrapped in aluminum foil and were stored at $4{ }^{\circ} \mathrm{C}$ until stored at $-80{ }^{\circ} \mathrm{C}$ in laboratory. Genomic DNA was extracted from the $0.2 \mu \mathrm{m}$ filters using ISOIL kit (Nippon Gene, Tokyo, Japan).

\section{PCR amplification}

The cyanobacterial 16S rRNA gene sequences were amplified by PCR using primers described by Nübel

et al. [20] (Table 1). The genomic DNA sample $(1 \mu \mathrm{l})$ recovered from each station was added to each 
93 round of PCR consisted of an initial 5 min denaturation at $95^{\circ} \mathrm{C}$, then 30 cycles of 1 min at $94^{\circ} \mathrm{C}, 1 \mathrm{~min}$ at

$9450^{\circ} \mathrm{C}$ and $1 \mathrm{~min}$ at $72^{\circ} \mathrm{C}$, and final elongation of $7 \mathrm{~min}$ at $72^{\circ} \mathrm{C}$. Of this reaction product, $1 \mu 1$ was transferred into a second $50 \mu \mathrm{l}$ reaction mixture containing the same reagent mixture, and primers were replaced with nifH1 and nifH2. The second round PCR consisted of an initial 5 min denaturation at $95^{\circ} \mathrm{C}$,

The amplified fragments were purified and cloned into pTac-1 vector (TOYOBO). We sequenced a total of 107 and 36 clones containing cyanobacterial 16S rRNA gene and nifH inserts, respectively. Basic Local Alignment Search Tool (BLAST) comparisons were used to find the sequence closely related to database [22]. The NifH phylogenetic tree based on the deduced amino acid sequences was constructed by the neighbour-joining method with Poisson correction using MEGA version 5 [23].

\section{Results}

111 The vertical thermal stratification was observed in surface water $(0-30 \mathrm{~m})$ of both Stn. 2 and Stn. 7 (Fig. 
temperature below $30 \mathrm{~m}$ depth declined gradually to 8.2 and $4.5^{\circ} \mathrm{C}$ at $200 \mathrm{~m}$ depth, respectively (Fig. 1).

114 Salinity of surface water in Stn. 2 was around 32.7 psu, which was a bit lower than that in Stn. 7 (33.3

psu) (Fig. 1). This lower salinity of Stn. 2 was considered to be derived from freshwater input from the

terrestrial area. In each station, the concentrations of chlorophyll $a$, the maximum of which was observed around $50 \mathrm{~m}$ depth, were extremely low $(<0.2 \mu \mathrm{M})$ compared with other oceanic regions [24].

We obtained a total of 107 clones of cyanobacterial 16S rRNA gene sequences from 12 samples in the Japan Sea (Table 2). Of these, 96 sequences (90\%) and 3 sequences (3\%) were assignable ( 99\% nucleotide similarity) to Synechococcus sub-cluster 5.1, and Prochlorococcus HL-(high-light) (II), respectively. In each station and depth, Synechococcus sub-cluster 5.1 dominated the cyanobactrial community. Of the 96 sequences assignable to Synechococcus sub-cluster 5.1, 6 sequences showed a 100\% identity with Synechococcus KORDI-19 which was isolated from the Japan Sea [25]. Residual 8 sequences (8\%) were assignable to Synechococcus sub-cluster 5.3. This type of sequences was recovered from samples ranging from 10-75 m depth in each station. In general, Prochlorococcus has two distinct ecotypes, the high-light(HL)- and low-light(LL)-adapted ecotypes[26]. The sequences similar to a subgroup of the HL ecotype, Prochlorococcus HL (II) were obtained only from surface water (0 m), regions of the euphotic zone [26-28]. No sequences assignable to the LL-Prochlorococcus were obtained, suggesting low abundance of LL-Prochlorococcus in the subsurface areas (Table 2).

131 We performed the nifH-targeting PCR amplification against the same 12 samples in the Japan Sea (Table 
samples of Stn. 2 at DCM, 75 m, $100 \mathrm{~m}$ and Stn. 7 at $100 \mathrm{~m}$, suggesting low abundance of diazotrophs in

134 these areas. On the basis of phylogenetic analysis, the nifH sequences were divided into five groups (Fig.

2). Sequences assigned to cyanobacteria showed a similarity to the sequences within UCYN-A, and accounted for $28 \%$ of the nifH clone library. All sequences assignable to UCYN-A were recovered from Stn. 7 at 30m, DCM, and $75 \mathrm{~m}$. This result is consistent with the observations that the peak abundances of UCYN-A was observed around $50 \mathrm{~m}$ depth in the Pacific Ocean [14]. Other sequences (72\%) were grouped within $\alpha-, \beta$-, and $\gamma$ - Proteobacteria. Sequences assigned as $\alpha$-Proteobacteria (Group 4) showed 100\% amino acid identity with sequences recovered from Baltic Sea and Chesapeake Bay (Fig. 2). In

$141 \quad \beta$-Proteobacteria, the sequences (Group 3) were recovered from Stn. 2 at 10m and Stn. 7 at 10m with $100 \%$ amino acid identity to Burkholderia vietnamensis G4 and sequences recovered from North Pacific Ocean. Burkholderia vietnamensis were also observed in reservoirs and agricultural settings [29]. Of sequences assigned to $\gamma$-Proteobacteria, 12 sequences were highly similar to protein sequences recovered from Atlantic Ocean, South China Sea and Mediterranean Sea.

\section{Discussion}

149 Marine Synechococcus is phylogenetically subdivided into three major subclusters, 5.1, 5.2, and 5.3. 
conditions [2,31-33]. Although surface water of the Japan Sea is extremely nutrient-limited environment

(eg. under-detection limit for $\mathrm{PO}_{4}, \mathrm{NO}_{3}, \mathrm{NO}_{2}$ ) [34], our data showed the dominance of Synechococcus in the cyanobacterial community. This discrepancy suggests unknown factors controlling their distribution in the Japan Sea, which will be the subject of future work. Synechococcus sub-cluster 5.3 accounted for $8 \%$ of the clone library with vertical distribution in each station [30, 35, 36] (Table 2). Huang et al. [30] report that their distribution may be restricted to certain oceanic regions because few sequences assignable to Synechococcus sub-cluster 5.3 were detected in the GOS database. However, their distribution and characteristics is not well understood. gene clone library. It is not surprising because the abundance of diazotrophic cyanobacteria is two to three orders of magnitude lower than that of Synechococcus or Prochlorococcus in most oceanic regions $[10,18,37,38]$. In nifH clone library, sequences belonging to UCYN-A were obtained from Stn. 7 at 30m, DCM, 75m depths. Due to the elevated phytoplankton biomass around DCM, the carbon source may be more readily available for UCYN-A lacking the carbon fixation enzyme Rubisco. Sequences related to other unicellular cyanobacteria (i.e. UCYN-B and C) were not detected in our nifH clone library. Moisander et al. [37] suggest the possibility of limiting the growth of UCYN-A and B by differential grazing pressure due to the smaller cell size of UCYN-A compared to UCYN-B. However, the factors of limiting the distribution of the unicellular diazotrophic cyanobacterial groups have not unraveled yet well. 
173 generation during diazotrophic growth [6]. As unicellular cyanobacteria have high surface/volume ratio

174 comparing to filamentous cyanobacteria, they may efficiently grow in oligotrophic environment because

175 phosphate uptake efficiency is dependent upon cell size [39]. Therefore, the presence of UCYN-A and no

176 detection of filamentous cyanobacteria may be due to the extremely nutrient poor condition in the Japan

177 Sea with iron repletion [34].

178 About two-thirds of nifH clones were derived from proteobacteria, and especisally sequences most related to $\gamma$-Proteobacteria were abundant. Although the sequences belonging to $\gamma$-Proteobacteria are detected in various oceans such as North Pacific Ocean and North Atlantic Ocean with accounting for a substantial fraction of the DNA/RNA nifH clone libraries, it is still unknown what extent these heterotrophic bacteria contribute to the net nitrtogen input in the ocean [40,41]. However, despite the low $\mathrm{N}_{2}$ fixation rates, heterotrophic bacteria dominated the diazotrophic community in the South Pacific with significant nitrogen input into the ocean [42]. Therefore, given the absence of other diazotrophic cyanobacteria, heterotrophic bacteria may account for substantial fraction of nitrogen input through $\mathrm{N}_{2}$ fixation in the Japan Sea. 
characteristics in the Japan Sea. We also showed that heterotrophic bacteria dominate the diazotrophic

\section{Acknowledgments}

This study was supported by Challenging Exploratory Research (No. 23658160).

\section{References}

1. Veldhuis MJW, Kraay GW, VanBleijswijk JDL, Baars MA (1997) Seasonal and spatial variability in phytoplankton biomass, productivity and growth in the northwestern Indian Ocean: the southwest and northeast monsoon. 1992-1993. Deep Sea Res Part I 44: 425-449.

2. Liu HB, Nolla HA, Campbell L (1997) Prochlorococcus growth rate and contribution to primary production in the equatorial and subtropical North Pacific Ocean. Aquat Microb Ecol 12: 39-47.

3. Li WKW (1994) Primary production of prochlorophytes, cyanobacteria, and eucaryotic ultraphytoplankton: Measurements from flow cytometric sorting. Limnol Oceanogr 39: 169-175.

4. Zehr JP (2011) Nitrogen fixation by marine cyanobacteria. Trends Microbiol 19: 162-173. significant marine cyanobacterium. Science 276: 1221-1229. Sea basin. Limnol Oceanogr 53: 1705-1721. 
216

217

218

219

220

221

223

224

225

226

227

228

229

230

231

232

233

234

235

236

237

238

239

240

241

242

243

244

7. Capone DG Burns JA, Michaels AF, Montoya JP, Subramaniam, A, Gunderson T, Carpenter EJ (2005) Nitrogen fixation by Trichodesmium spp.: An important source of new nitrogen to the tropical and subtropical North Atlantic Ocean. Glob Biogeochem Cycles 19: 786-787.

8. Mague TH, Weare NM, Holm-Hansen O (1974) Nitrogen fixation in the north Pacific Ocean. Mar Biol 24: 109-119.

9. Foster RA, Kuypers MMM, Vagner T, Paerl RW, Musat N, Zehr JP (2011) Nitrogen fixation and transfer in open ocean diatom-cyanobacterial symbioses. ISME J 5: 1484-1493.

10. Church MJ, Björkman KM, Karl DM, Saito MA, Zehr JP (2008) Regional distributions of nitrogen-fixing bacteria in the Pacific Ocean. Limnol Oceanogr 53: 63-77.

11. Foster RA, Subramaniam A, Mahaffey C, Carpenter EJ, Capone DG, Zehr JP (2007) Influence of the Amazon River plume on distributions of free-living and symbiotic cyanobacteria in the western tropical north Atlantic Ocean. Limnol Oceanogr 52: 517-532.

12. Church MJ, Mahaffey C, Letelier RM, Lukas R, Zehr JP, Karl DM (2009) Physical forcing of nitrogen fixation and diazotroph community structure in the North Pacific subtropical gyre. Glob Biogeochem Cycles 23. GB2020, doi:10.1029/2008GB003418.

13. Montoya JP, Holl CM, Zehr JP, Hansen A, Villareal TA, Capone DG (2004) High rates of $\mathrm{N}_{2}$ fixation by unicellular diazotrophs in the oligotrophic Pacific Ocean. Nature 430: 1027-1031.

14. Moisander PH, Beinart RA, Hewson I, White AE, Johnson KS, Carlson CA, Montoya JP, and Zehr JP (2010) Unicellular cyanobacterial distributions broaden the oceanic $\mathrm{N}_{2}$ fixation domain. Science 327: 1512-1514.

15. Zehr JP, Bench SR, Carter BJ, Hewson I, Niazi F, Shi T, Tripp J, Affourtit JP (2008) Globally Distributed Uncultivated Oceanic $\mathrm{N}_{2}$-Fixing Cyanobacteria Lack Oxygenic Photosystem II. Science 322: 1110-1112.

16. Staal M, Hekkert ST, Brummer GJ, Veldhuis M, Sikkens C, Persijn S, Stal LJ (2007) Nitrogen fixation along a north-south transect in the eastern Atlantic Ocean. Limnol Oceanogr 52: 1305-1316.

17. Needoba JA, Foster RA, Sakamoto C, Zehr JP, Johnson KS (2007) Nitrogen fixation by unicellular diazotrophic cyanobacteria in the temperate oligotrophic North Pacific Ocean. Limnol Oceanogr 52: $1317-1327$. 
245

246

247

248

249

250

251

252

253

254

256

257

258

259

260

261

262

18. Goebel NL, Turk KA, Achilles KM, Paerl R, Hewson I, Morrison AE. Montoya JP, Edwards CA, Zehr JP (2010) Abundance and distribution of major groups of diazotrophic cyanobacteria and their potential contribution to $\mathrm{N}_{2}$ fixation in the tropical Atlantic Ocean. Environ Microbiol 12: $3272-3289$.

19. Ichiye T (1984) Some problems of circulation and hydrography of the Japan Sea and the Tsushima Current. Ocean hydrodynamics of the Japan and East China Seas. Elsevier, Netherlands, pp. $15-54$.

20. Nübel U, Garcia-Pichel F, Muyzer G (1997) PCR primers to amplify 16S rRNA genes from cyanobacteria. Appl Environ Microbiol 63:3327-3332.

21. Zehr JP, Turner PJ (2001) Nitrogen Fixation: Nitrogenase Genes and Gene Expression. Methods Microbiol 30: 271-286.

22. Altschul SF, Madden TL, Schäffer AA, Zhang J, Zhang Z, Miller W, Lipman DJ (1997) Gapped BLAST and PSI-BLAST: a new generation of protein database search programs. Nucleic Acids Res 25: 3389-3402.

23. Tamura K, Peterson D, Peterson N, Stecher G, Nei M and KS (2011) MEGA5: Molecular Evolutionary Genetics Analysis using Maximum Likelihood, Evolutionary Distance, and Maximum Parsimony Methods. Mol Biol Evol doi:10.1093/molbev/msr121.

24. Dasgupta S, Singh RP, Kafatos M (2009) Comparison of global chlorophyll concentrations using MODIS data. Adv Space Res 43: 1090-1100.

25. Choi DH, Noh JH (2009) Phylogenetic diversity of Synechococcus strains isolated from the East China Sea and the East Sea. FEMS Microbiol Ecol 69: 439-448.

26. Rocap G, Larimer FW, Lamerdin J, Malfatti S, Chain P, Ahlgren NA, Arellano A, Coleman M, Hauser L, Hess WR, Johnson ZI, Land M, Lindell D, Post AF, Regala W, Shah M, Shaw SL, Steglich C, Sullivan MB, Ting CS, Tolonen A, Webb EA, Zinser ER, Chisholm SW. (2003) Genome divergence in two Prochlorococcus ecotypes reflects oceanic niche differentiation. Nature 424: 1042-1047.

27. Ahlgren NA, Rocap G, Chisholm SW (2006) Measurement of Prochlorococcus ecotypes using real-time polymerase chain reaction reveals different abundances of genotypes with similar light physiologies. Environ Microbiol 8: 441-454. 
274

275

276

277

278

279

280

281

282

283

284

285

286

287

288

289

290

291

292

293

294

295

296

297

298

299

300

301

302

303

304

28. Zinser ER, Coe A, Johnson ZI, Martiny AC, Fuller NJ, Scanlan DJ, Chisholm SW. (2006) Prochlorococcus ecotype abundances in the north atlantic ocean as revealed by an improved quantitative PCR method. Appl Environ Microbiol 72: 723-732.

29. Menard A, Monnez C, Santos PEDL, Segonds C, Caballero-Mellado J, LiPuma, JJ, Chabanon G, Cournoyer B. (2007) Selection of nitrogen-fixing deficient Burkholderia vietnamiensis strains by cystic fibrosis patients: involvement of nif gene deletions and auxotrophic mutations. Environ Microbiol 9: 1176-1185.

30. Huang S, Wilhelm SW, Harvey HR, Taylor K, Jiao N, Chen F. (2011) Novel lineages of Prochlorococcus and Synechococcus in the global oceans. ISME J 6: 285-297.

31. Johnson ZI, Zinser ER, Coe A, McNulty NP, Woodward EM, Chisholm SW. (2006) Niche partitioning among Prochlorococcus ecotypes along ocean-scale environmental gradients. Science 311: 1737-1740.

32. Olson RJ, Chisholm SW, Zettler ER, Altabet MA, Dusenberry JA. (1990) Spatial and temporal distributions of prochlorophyte picoplankton in the North Atlantic Ocean. Deep-Sea Res Part A 37: 1033-1051.

33. Bouman HA, Ulloa O, Scanlan DJ, Zwirglmaier K, Li WKW, Platt T, Stuart V, Barlow R, Leth O, Clementson L, Lutz V, Fukasawa M, Watanabe S, Sathyendranath S. (2006) Oceanographic basis of the global surface distribution of Prochlorococcus ecotypes. Science 312: 918-921.

34. Takata H, Kuma K, Iwade S, Isoda Y, Kuroda H, Senjyu T (2005) Comparative vertical distributions of iron in the Japan Sea, the Bering Sea, and the western North Pacific Ocean. J Geophys Res Lett 33, L02613, doi:10.1029/2005GL024538.

35. Dufresne A, Ostrowski M, Scanlan DJ, Garczarek L, Mazard S, Palenik BP, Paulsen IT, Tandeau de Marsac N, Wincker P, Dossat C, Ferriera S, Johnson J, Post AF, Hess WR, Partensky F. (2008) Unraveling the genomic mosaic of a ubiquitous genus of marine cyanobacteria. Genome Biol 9:R90.

36. Scanlan DJ, Ostrowski M, Mazard S, Dufresne A, Garczarek L, Hess WR, Post AF, Hagemann M, Paulsen I, Partensky F. (2009) Ecological genomics of marine picocyanobacteria. Microbiol Molecul Biol Rev 73: 249-299.

37. Moisander PH, Zhang R, Boyle EA, Hewson I, Montoya JP, Zehr JP. (2012) Analogous nutrient limitations in unicellular diazotrophs and Prochlorococcus in the South Pacific Ocean. ISME J 6: 733-744. 
305

306

307

308

309

310

38. Zwirglmaier K, Jardillier L, Ostrowski M, Mazard S, Garczarek L, Vaulot D, Not F, Massana R, Ulloa O, Scanlan DJ. (2008) Global phylogeography of marine Synechococcus and Prochlorococcus reveals a distinct partitioning of lineages among oceanic biomes. Environ Microbiol 10: 147-161.

39. Smith REH, Kalff J (1982) Size-dependent phosphorus uptake kinetics and cell quota in phytoplankton. J Phycol 18: 275-284.

40. Langlois RJ, Hümmer D, LaRoche J (2008) Abundances and distributions of the dominant nifH phylotypes in the Northern Atlantic Ocean. Appl Environ Microbiol 74: 1922-1931.

41. Moisander PH, Beinart RA, Voss M, Zehr JP (2008) Diversity and abundance of diazotrophic microorganisms in the South China Sea during intermonsoon. ISME J 2: 954-967.

42. Halm H, Lam P, Ferdelman TG, Lavik G, Dittmar T, LaRoche J, D'Hondt S, Kuypers MMM. (2011) Heterotrophic organisms dominate nitrogen fixation in the South Pacific Gyre. ISME J 6:1238-1249. 
Figure 1

Vertical distributions (0-200 m) of temperature, salinity, chlorophyll $a$ concentrations ( $\left.\mathrm{mg} \mathrm{m}^{-3}\right)$ at $\mathrm{Stn} .2$

\section{Figure 2}

Phylogenetic trees for nifH-deduced amino acid sequences from each sample constructed using the

neighbor-joining method. Bootstrap values greater than $50 \%$ for 1000 replicates are indicated at

respective nodes. Database entries for sequences are as follows: Azotobacter chroococcum

strain NRRL B-14637 (AAR11505); Pseudomonas stutzeri A1501 (YP_001171863); Vibrio

diazotrophicus clone CC1104A1 (AAP48983); Sinorhizobium meliloti bv (ABC67302);

Azospirillum brasilense (P17303); Rhodopseudomonas sp. 99D (BAC07290); Rhodobacter

sphaeroides 2.4.1 (YP_353614); Burkholderia vietnamiensis G4 (YP_001115195);

Rhodoferax antarcticus strain ANT.BR. clone 685K1_sp6 (ABI14697); Sphingomonas

azotifigens (BAE71134); Bradyrhizobium japonicum USDA 110 (BAC47034); Xanthobacter 
352

353

354

355

356

357

358

359

360

361

362

363

364

365

366

367

368

369

370

371

372 Hashimoto et al., Figure 1 sp. TW3 (BAJ21365); Unidentified marine bacterial clone HT1902 (AAK83129); Uncultured marine bacterium clone TAP14405 (AAY60051); Cyanobacterium UCYN-A (ACJ53724);

Oscillatoria sancta clone CC1091A1 (AAP48970); Trichodesmium thiebautii (AAA77023);

Trichodesmium erythraeum IMS101 (AAA77022); Methanosarcina acetivorans C2A (NP_616144) 

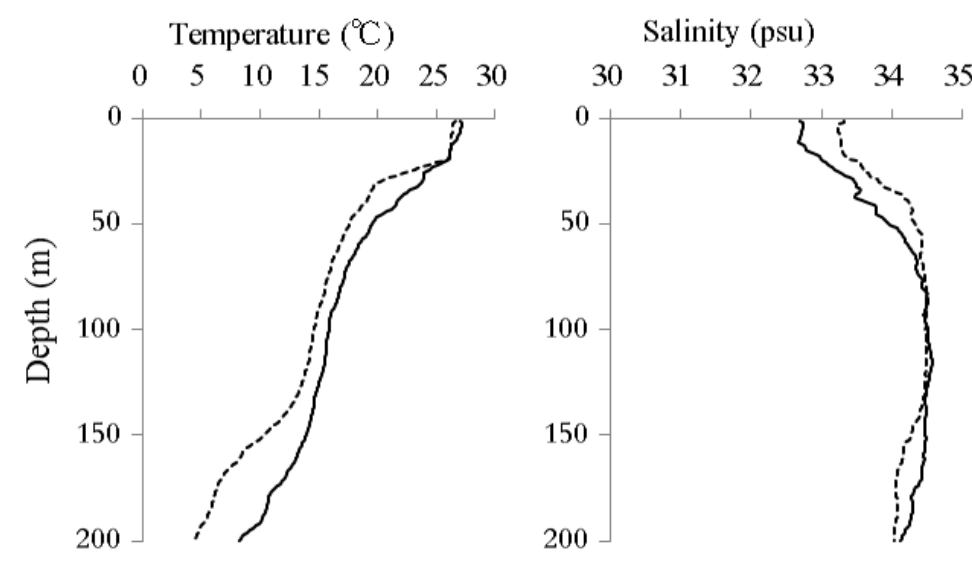

\section{Chl a $\left(\mathrm{mg} \mathrm{m}^{-3}\right)$}

$\begin{array}{lllllll}35 & 0.0 & 0.1 & 0.2 & 0.3 & 0.4 & 0.5\end{array}$



$\begin{array}{lr}- & \text { Stn. } 2 \\ ---- & \text { Stn. } 7\end{array}$ 
388

389

390

391

392

393

394

395

396

397

398

399

400

401

402

100

St7-surfac

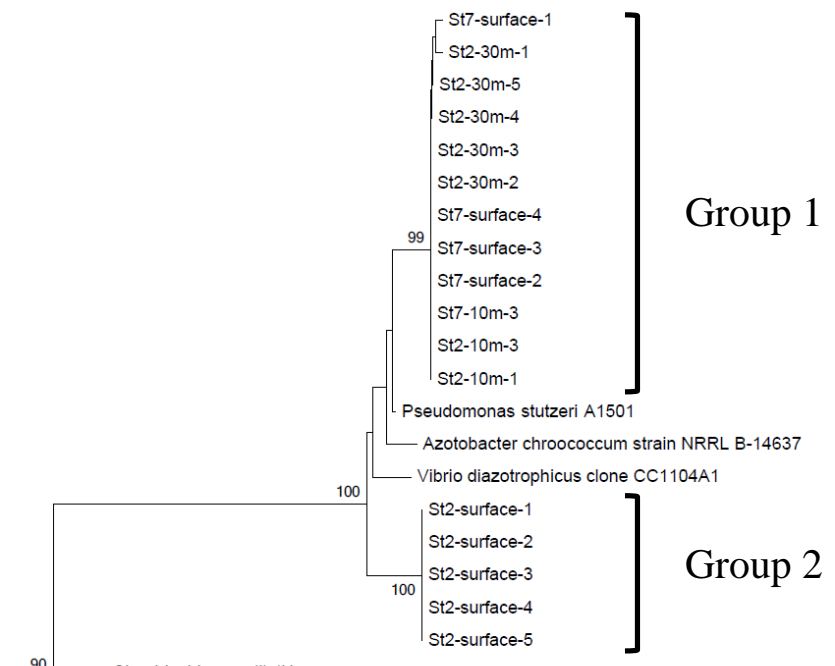

${ }_{64}^{90}\left[\begin{array}{c}\text { Sinorhizobium meliloti bv } \\ \text { Azospirillum brasilense }\end{array}\right.$

Rhodopseudomonas sp. 99D

95 Rhodobacter sphaeroides 2.4 .1

St7-10m-1

${ }_{93}$ St7-10m-2

$81 \quad 93 \mathrm{St} 2-10 \mathrm{~m}-4$

69 St2-10m-2

Burkholderia vietnamiensis G4

Rhodoferax antarcticus strain ANT.BR. clone 685K1 sp6

Group 3

- Sphingomonas azotifigens

Bradyrhizobium japonicum USDA 110

- Xanthobacter autotrophicus Py2

$66\left[\begin{array}{l}\text { St7-peak-3 } \\ \text { St7-peak-4 }\end{array}\right.$

St7-peak-4

$97 \begin{aligned} & \text { St7-peak-5 } \\ & \text { St7-peak-6 }\end{aligned}$

St7-peak-7

Crocosphaera watsonii WH 8501

Lyngbya lagerheimii UTEX 1930

Cyanothece sp. WH 8902

Cyanothece sp. TW3

98 Gloeothece sp. KO68DGA

Gloeothece sp. SK40

Cyanothece ATCC51142

St7-75m-3

- Unidentified marine bacterial clone $\mathrm{HT} 1902$

Group 4

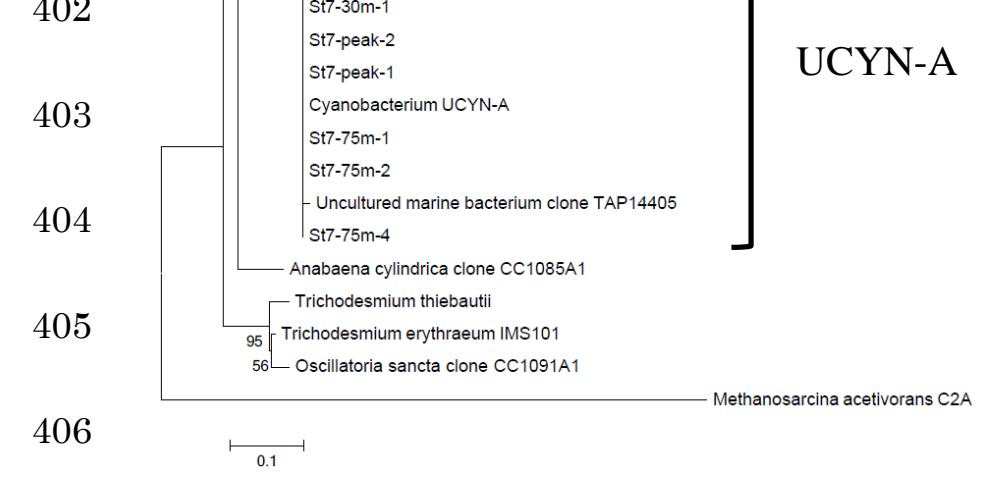

Cyanobacteria

$\alpha, \beta$-Proteobacteria

Table 1. Cyanobacterial 16S rRNA and nifH primers used in this study. 


\begin{tabular}{llll}
\hline Primer & Target site & Sequence(5'-3') & Reference \\
\hline CYA359F & 16S rRNA of cyanobacteria & GGG GAA TYT TCC GCA ATG GG & Nübel et al. 1997 \\
CYA781R(a) & 16S rRNA of cyanobacteria & GAC TAC TGG GGT ATC TAA TCC CAT T & Nübel et al. 1997 \\
CYA781(b) & 16S rRNA of cyanobacteria & GAC TAC AGG GGT ATC TAA TCC CTT T & Nübel et al. 1997 \\
nifH1 & nifH of prokaryotes & TGY GAY CCN AAR GCN GA & Zehr and McReynolds 1989 \\
nifH2 & nifH of prokaryotes & AND GCC ATC ATY TCN CC & Zehr and McReynolds 1989 \\
nifH3 & nifH of prokaryotes & ATR TTR TTN GCN GCR TA & Zani et al. 2000 \\
nifH4 & nifH of prokaryotes & TTY TAY GGN AAR GGN GG & Zani et al. 2000 \\
\hline
\end{tabular}

423 Table 2. Summary of cyanobacterial 16S rRNA gene clones obtained from each microbial group. 


\begin{tabular}{|c|c|c|c|c|c|}
\hline \multirow[b]{2}{*}{ Station } & \multirow[b]{2}{*}{ Depth } & \multicolumn{3}{|c|}{ Number of Clones } & \multirow[b]{2}{*}{ Total } \\
\hline & & $\begin{array}{l}\text { Synechococcus } \\
\text { sub-cluster } 5.1\end{array}$ & $\begin{array}{l}\text { Synechococcus } \\
\text { sub-cluster } 5.3\end{array}$ & $\begin{array}{l}\text { Prochlorococcus } \\
\text { HL(II) }\end{array}$ & \\
\hline \multirow[t]{6}{*}{2} & $0 \mathrm{~m}$ & 7 & & 2 & 9 \\
\hline & $10 \mathrm{~m}$ & 9 & 1 & & 10 \\
\hline & $30 \mathrm{~m}$ & 9 & 1 & & 10 \\
\hline & DCM & 8 & 2 & & 10 \\
\hline & $75 \mathrm{~m}$ & 8 & & & 8 \\
\hline & $100 \mathrm{~m}$ & 9 & 1 & & 10 \\
\hline \multirow[t]{6}{*}{7} & $0 \mathrm{~m}$ & 9 & & 1 & 10 \\
\hline & $10 \mathrm{~m}$ & 10 & & & 10 \\
\hline & $30 \mathrm{~m}$ & 9 & 1 & & 10 \\
\hline & DCM & 9 & 1 & & 10 \\
\hline & $75 \mathrm{~m}$ & 9 & 1 & & 10 \\
\hline & $100 \mathrm{~m}$ & & & & - \\
\hline
\end{tabular}

424

425

426

427

428

429

430

431

432

433

434

435

Table 3. Summary of nifH clones obtained from each microbial group. 


\begin{tabular}{|c|c|c|c|c|c|}
\hline \multirow[b]{2}{*}{ Station } & \multirow[b]{2}{*}{ Depth } & \multicolumn{3}{|c|}{ Number of Clones } & \multirow[b]{2}{*}{ Total } \\
\hline & & $\begin{array}{l}\text { Cyanobacterium } \\
\text { UCYN-A }\end{array}$ & $\begin{array}{l}\alpha-, \beta- \\
\text { Proteobacteira }\end{array}$ & $\begin{array}{l}\gamma- \\
\text { Proteobacteria }\end{array}$ & \\
\hline \multirow[t]{6}{*}{2} & $0 \mathrm{~m}$ & & & 5 & 5 \\
\hline & $10 \mathrm{~m}$ & & 2 & 2 & 4 \\
\hline & $30 \mathrm{~m}$ & & & 5 & 5 \\
\hline & DCM & & & & - \\
\hline & $75 \mathrm{~m}$ & & & & - \\
\hline & $100 \mathrm{~m}$ & & & & - \\
\hline \multirow[t]{6}{*}{7} & $0 \mathrm{~m}$ & & & 4 & 4 \\
\hline & $10 \mathrm{~m}$ & & 2 & 1 & 3 \\
\hline & $30 \mathrm{~m}$ & 4 & & & 4 \\
\hline & DCM & 2 & 5 & & 7 \\
\hline & $75 \mathrm{~m}$ & 4 & & & 4 \\
\hline & $100 \mathrm{~m}$ & & & & - \\
\hline
\end{tabular}

436

437 